\title{
Staycation and Leisure Time Analysis during The Covid-19 Pandemic
}

\author{
Rudhya Nurul Ilma ${ }^{1}$, Muktiarni ${ }^{2,}$, Jonah Mupita ${ }^{3}$ \\ ${ }^{1}$ Departemen Pendidikan Biologi, Universitas Pendidikan Indonesia, Indonesia \\ ${ }^{2}$ Departemen Tata Boga, Universitas Pendidikan Indonesia, Indonesia \\ ${ }^{3}$ Ruya Adventist High School, Zimbabwe \\ *Corresponding author : muktiarni@upi.edu
}

\begin{abstract}
Abstrak: Banyaknya perubahan akibat dari adanya pandemi Covid-19 membuat masyarakat perlu menyesuaikan diri dengan kebiasaan baru dan sebagian besar aktivitas tersebut dilakukan di rumah. Kegiatan pengabdian ini berupa pemberian pemahaman dan saran terkait aktivitas yang dapat dilakukan selama pandemi untuk anak-anak serta mengisi waktu luang yang dimiliki agar lebih produktif. Pengukuran keefektifan dari kegiatan ini dilakukan dengan memberikan pertanyaan sebelum kegiatan (pretest) dan setelah kegiatan (posttest) kemudian membandingkan hasilnya. Objek kegiatan adalah siswa kelas VB Sekolah Dasar. Hasil kegiatan menunjukkan bahwa sebelum pemberian materi sudah banyak siswa yang mengetahui istilah staycation dari media massa namun belum terlalu paham terkait pemanfaatan waktu luang. Setelah pemberian materi banyak siswa yang mulai paham terkait pemanfaatan waktu luang dengan kegiatan yang lebih produktif, misalnya membaca. Mereka juga mulai terbiasa dengan kegiatan literasi sebelum memulai kegiatan pembelajaran daring, sehingga dapat meningkatkan minat baca siswa dan menumbuhkan kebiasaan literasi.
\end{abstract}

Kata kunci: Covid-19, staycation, waktu luang.

Abstract: The many changes as a result of the Covid-19 pandemic make people need to adjust to new habits and most of these activities are carried out at home. This community service is in the form of providing understanding and advice regarding activities that can be done during the pandemic for children and to fill their leisure time to be more productive. Measurement of the effectiveness of this activity is done by asking questions before the activity (pretest) and after the activity (posttest) and then comparing the results. The object of the activity is elementary school VB class students. The results of the activity showed that before giving the material, many students knew the term staycation from the mass media but did not really understand the use of leisure time. After giving the material, many students began to understand the use of leisure time with more productive activities, such as reading. They also get used to literacy activities before starting online learning activities, so that they can increase students' reading interest and foster literacy habits.

Keywords: Covid-19, leisure time, staycation. 


\section{Introduction}

Indonesia first announced positive COVID-19 patients on March 2, 2020, which was followed by the establishment of various policies to prevent the spread of the COVID-19 Virus. In response to the spread of the COVID-19 Virus, the Indonesian government has implemented various policies, both written and unwritten. These policies include staying at home, social distancing, physical distancing, use of personal protective equipment (masks), maintaining personal hygiene (washing hands), work and study at/from home, postpone all activities that gather large crowds, large-scale social restrictions, until the last, the implementation of the New Normal Policy (Tuwu, 2020).

Several similar studies have discussed staycations and the use of leisure time. Schooler \& Mulatu (2001) showed that in old age doing productive things that are quite complicated in their spare time can help expand their capacity to face intellectual challenges that occur in their environment elderly. Another study stated that the most of those who do staycations are young people or adults with a millennial lifestyle (James et al., 2017). Meanwhile, Bafadhal (2021) proposed that staycation during covid-19 pandemic with virtual tourism. Francken \& van Raaij (1981) discussed the satisfaction when filling leisure time which explains the limitations and satisfaction of each person in spending their leisure time according to social class. A questionnaire for the assessment of leisure time physical activities (Taylor et al., 1978). Occupation, hours worked, and leisure-time physical activity (Burton and Turrell, 2000). Discussion on the Analysis of the Impact of the Covid-19 Pandemic on Family Harmony also stated that the many changes in daily routines due to the pandemic mostly had a negative impact on family harmony due to declining social, economic and health conditions (Afifah, 2021). The impact of understanding the mental health of students in Indonesia on psychological first aid also supports this activity because it is still related to the impact of covid-19 (Princess, 2021).

In previous studies, there have been discussions about staycation and the use of leisure time like a descriptive epidemiology of leisure-time physical activity (Stephens et al., 1985), but not too many have discussed related to staycations by utilizing leisure time by habituation of literacy activities in it. Therefore, the authors conducted activity with the aim of knowing an increase in students' understanding of staycation and the use of leisure time and reading literacy skills through e-books and physical books. The study used a quantitative approach using a preexperimental method in the form of a one-group pre-test-post-test design. The activity results were analyzed using descriptive statistics by comparing the mean scores on the pretest with the 
post-test.

\section{Methods}

In this study, the type of method used is quantitative activity using the pre-experimental design method, type one group pre-test-post-test. The data collection technique used in this study is an online questionnaire method via google form to find out how much knowledge elementary school students have about staycation and the use of leisure time. The population in this study were students of class VB elementary school. The sample used in this study were 10 students of class VB elementary school through google form. This activity was conducted through 2 stages, divided into 2 sessions, the first is the pre-test, which is before the learning video is delivered and the second is the post-test, which is after the learning video is delivered to determine the extent of understanding of the material presented. The designed instrument is in the form of a two-choice Likert scale (yes and no). The data obtained will be processed and then compared until finally the results will be concluded.

A staycation is defined as a vacation where tourists stay at home, or near home, while creating a simple vacation environment. Vackova provides the same definition, namely a place to live or a space where tourists stay at home instead of traveling to other destinations and using the leisure time at that time to explore the surrounding environment; Like staying in a city hotel or exploring the countryside near their home (James et al., 2017).

\section{Results and Discussion}

\subsection{Demography}

This activity was conducted in elementary schools. The first step in this activity is a survey of the number of students in class VB by interviewing the homeroom teacher of class VB. The number of registered students is twenty-six students. Then we selected a sample from the population and obtained as many as ten students with details of men as much as $50 \%$ (five students) and women as much as 50\% (five students).

\subsection{Pre-test and post-test result}

Currently, learning activities in elementary schools are carried out online. The tools and media used in learning are through google meet, google classroom, and google form. Activities distributed google forms to students through chat groups via WhatsApp. The first questionnaire that was made was a pre-test questionnaire. The making of this questionnaire was distributed 
to elementary school VB class students with the aim of knowing and analyzing the level of students' understanding of the use of leisure time and staycation activities by filling out ten questions. After that, we will provide a learning video. After giving the learning video material and discussing, we are disseminating the limb with the same problem of post-test to students so that we can determine the extent of their understanding of the term staycation and how to use their time.

Table 1 contains a list of questions and the percentage of pre-test and post-test results from a total of ten questions. The questions given are only in the form of Yes and No choices and there is one question that has answer choices in the form of reading, writing, sports, and playing. The answer options were made with the aim of knowing the extent to which the literacy level of the VB grade elementary school students to fill their spare time with reading activities after the literacy program was held ten minutes before the teaching and learning activities began and retold what they had read.

Table 1. Pre-test and post-test question along with the percentage of answer

\begin{tabular}{|c|c|c|c|}
\hline Number & Question & Pre-Test & Post-Test \\
\hline 1. & Are you following the advice to stay at home? & $100 \%$ & $100 \%$ \\
\hline 2. & $\begin{array}{l}\text { Do you have more leisure time during the Covid-19 } \\
\text { pandemic? }\end{array}$ & $100 \%$ & $100 \%$ \\
\hline 3. & $\begin{array}{l}\text { Have you ever taken a vacation or traveled during a } \\
\text { pandemic? }\end{array}$ & $18.2 \%$ & $11.1 \%$ \\
\hline 4. & Do you know the term staycation? & $36.4 \%$ & $61.1 \%$ \\
\hline 5. & $\begin{array}{l}\text { If there are tourist activities that can be done in one place } \\
\text { and have many activities that can be done, would you } \\
\text { choose this tour to fill your spare time? }\end{array}$ & $36.4 \%$ & $61.1 \%$ \\
\hline 6. & Do you still often play outside the house? & $45.5 \%$ & $27.8 \%$ \\
\hline 7. & $\begin{array}{l}\text { Does staying at home for too long make you feel } \\
\text { depressed and bored? }\end{array}$ & $90.9 \%$ & $66.7 \%$ \\
\hline 8. & $\begin{array}{l}\text { Do you often spend leisure time at home with your } \\
\text { family? }\end{array}$ & $72.7 \%$ & $83.3 \%$ \\
\hline 9. & $\begin{array}{l}\text { Did the situation during the pandemic make you lose } \\
\text { your enthusiasm for learning? }\end{array}$ & $100 \%$ & $61.1 \%$ \\
\hline 10. & What do you do to fill your spare time? (Read) & $18.2 \%$ & $50 \%$ \\
\hline & Mean & $61.83 \%$ & $62.22 \%$ \\
\hline
\end{tabular}

Figure 1 shows the level of understanding of elementary school VB students regarding staycation activities and the use of leisure time is more productive when given a pre-test, the level of understanding is $61.83 \%$. After the students were given the material, the level of understanding of the students increased by $62.22 \%$. Based on these results, there is an increase in students' knowledge of $0.39 \%$. The increase in knowledge is because students have seen learning videos, discussed, so they are able to understand the material presented. 


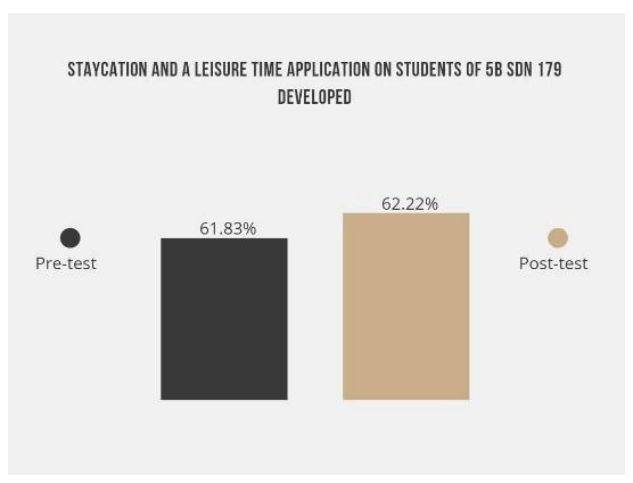

Figure 1. Bar chart which show a comparison of the pre-test and post-test results

The COVID-19 pandemic has brought many changes in terms of social, economic, educational, environmental, and so on. The pattern of people's lives has changed because of these policies. The COVID-19 pandemic is not only a global health crisis but has also affected the daily lives of people around the world (Rice et al., 2020).

The benefits of filling spare time according to Soetarlinah Sukadji (Triatmoko, 2007), namely, a) Can improve physical wellbeing; b) Increase mental and emotional freshness; c) Makes us recognize our own abilities; d) Supports self-concept and self-esteem; e) Learning facilities and ability development; f) Expression and balance physical, mental, intellectual, spiritual, and aesthetic; g) Make appreciation of what you like without ignoring the material aspect. Apart from that, filling leisure time also serves to fulfill social needs, such as improving community life. The benefits of filling leisure time can be felt if the use of leisure time is in accordance with the needs, such as improving social life.

\section{Conclusion}

The conclusion of this study shows that before providing material through learning videos, many students know the term staycation from the mass media but do not really understand the use of leisure time. After giving the material, many students began to understand the use of leisure time with more productive activities, one of which was reading. They also began to get used to literacy activities before starting online learning activities. The interest in doing staycations has also increased because parents feel it is safer. In addition, a staycation can also improve family welfare and harmony because it can help relieve stress due to boredom after a long period of quarantine. 


\section{Acknowledgement}

We acknowledged Bangdos, Universitas Pendidikan Indonesia. We thank to Rusmiati Nurdahniar, S.Pd from Sekolah Dasar Negeri 179 Sarijadi. This activity is a part of community service organized by Lembaga Penelitian dan Pengabdian Masyarakat (LPPM), Universitas Pendidikan Indonesia in "KKN Tematik Literasi 2021" Program during August-September 2021. We also thank to Kantor Jurnal dan Publikasi, Directorate of International Affairs, Universitas Pendidikan Indonesia. We thank to Nissa Nur Azizah, Dwi Fitria Al Husaeni, Dr.Eng. Asep Bayu Dani Nandiyanto, S.T., M.Eng., M.Pd., Rina Maryanti, S.Pd., M.Pd., and Asri Wibawa Sakti, M.Pd.

\section{References}

Afifah, Q. A. 2021. Analysis of the Impact of the covid-19 pandemic on family harmony: case studies on family with and without people with special needs. Indonesian Journal of Community and Special Needs Education, 1(2), 87-92.

Bafadhal, A. S. 2021. Staycation During COVID-19 Pandemic with Virtual Tourism: TeleTourist Attitude Toward Experience in Cultural Heritage Destination. Journal of Indonesian Tourism and Development Studies, 9(2), 87.

Burton, N. W. \& Turrell, G. 2000. Occupation, hours worked, and leisure-time physical activity. Preventive medicine, 31(6), 673-681.

Francken, D. A. \& Van Raaij, W. F. 1981. Satisfaction with leisure time activities. Journal of Leisure Activity, 13(4), 337-352.

James, A., Ravichandran, S., Chuang, N. K., \& Bolden III, E. 2017. Using lifestyle analysis to develop lodging packages for staycation travelers: An exploratory study. Journal of Quality Assurance in Hospitality \& Tourism, 18(4), 387-415.

Putri, R. M. 2021. The effect of understanding student mental health in Indonesia on psychological first aid. Indonesian Journal of Community and Special Needs Education, 1(1), 9-10.

Schooler, C. \& Mulatu, M. S. 2001. The reciprocal effects of leisure time activities and intellectual functioning in older people: a longitudinal analysis. Psychology and aging, 16(3), 466.

Stephens, T., Jacobs Jr, D. R., \& White, C. C. 1985. A descriptive epidemiology of leisuretime physical activity. Public health reports, 100(2), 147.

Taylor, H. L., Jacobs Jr, D. R., Schucker, B., Knudsen, J., Leon, A. S. \& Debacker, G. 1978. 
A questionnaire for the assessment of leisure time physical activities. Journal of chronic diseases, 31(12), 741-755.

Tuwu, D. 2020. Kebijakan pemerintah dalam penanganan pandemi Covid-19. Journal Publicuho, 3(2), 267-278. 